\title{
Economics
}

2015; 4(5): 71-80

Published online August 25, 2015 (http://www.sciencepublishinggroup.com/j/eco) doi: 10.11648/j.eco.20150405.11

\section{Economic Valuation of Forest Ecosystems Service's Role in Maintaining and Improving Water Quality}

\author{
Bamlaku Ayenew ${ }^{1, *}$, Yemiryu Tesfay ${ }^{2}$ \\ ${ }^{1}$ Hawassa University Wondo Genet Collage of Forestry and Natural Resources, School of Natural Resource and Environmental Studies, \\ Hawassa, Ethiopia \\ ${ }^{2}$ Hawassa University Wondo Genet Collage of Forestry and Natural Resources, School of Forestry, Hawassa, Ethiopia
}

Email address:

bam107@yahoo.com (B. Ayenew), yemiru.tesfaye@slu.se (Y. Tesfay)

\section{To cite this article:}

Bamlaku Ayenew, Yemiryu Tesfay. Economic Valuation of Forest Ecosystems Service's Role in Maintaining and Improving Water Quality. Economics. Vol. 4, No. 5, 2015, pp. 71-80. doi: 10.11648/j.eco.20150405.11

\begin{abstract}
The objective of this paper was to review the economic value of forest ecosystem services especially in maintaining and improving water quality and also to highlight the commonly applied techniques that are applied in the valuation of these economic values. The importance of natural forest ecosystems to human well-being cannot be overstated. What this review makes clear that forest ecosystem service provides important portion of the total contribution to economic development and social welfare in the maintaining and improving water quality. Water in adequate quantity and quality to meet human needs is essential, and forests have direct and indirect roles in providing such water. However, in order for conservation of forest areas to be economically feasible, such forest areas need to secure a financial return in excess of alternative uses. It is increasingly recognized that both the availability and the quality of water are strongly influenced by forests and that water resources in many regions are under growing threat from overuse, misuse and pollution. The relationship between forests and water is therefore a critical issue that must be accorded high priority. A key challenge for land, forest and water managers is maximizing the wide range of forest benefits without detriment to water resources and ecosystem function. To address this challenge, there is urgent need for better understanding of the interactions between forests/trees and water (particularly in watersheds), for awareness raising and capacity building in forest hydrology, and for embedding this knowledge and research findings in policies. There is also need to develop institutional mechanisms to enhance synergies in forests and water issues, and to implement and enforce national and regional action programmes.
\end{abstract}

Keywords: Ecosystem Services of Forests, Economic Valuation, Runoff, Water Quality

\section{Introduction}

\subsection{The Definition of Ecosystem}

An ecosystem is a biologicalenvironment consisting of all the organisms living in a particular area, as well as all the nonliving, physical components of the environment with which the organisms interact, such as air, soil, water, and sunlight (Wikipedia, 2010). While Ecosystem service is any services generates by Ecosystem that provide utility to well being of the people. However, there is the debate on how they define ecosystem services by scientists, particularly in relation to processes and functions. Daily (1997) defines ecosystem services as: "the conditions and processes through which natural ecosystems and the species that make them up, sustain and fulfill human life". Here, services encompass functions and processes. Costanza et al. (1997) define functions as "the habitat, biological or system properties or processes of ecosystems". Services, then, are the benefits humans derive from these functions. According to him, Environmental functions include regulation function, habitat function, information function and production. Examples of regulation function are: climate control, water regulation, soil and nutrient regulation etc. Example of Production function: raw material, food, medicinal etc. Habitat regulations are: reproduction and breeding. Examples of information function are: aesthetic value, cultural and spiritual value, education value (Hawkins, 2003).

Forests are one of the most valuable terrestrial ecosystems that provide variable goods and services (de Groot et al 2002). A forest ecosystem is a dynamic complex of plant, animal and 
micro-organism communities and their abiotic environment interacting as a functional unit, where trees are a key component of the system. Humans, with their cultural, economic and environmental needs are an integral part of many forest ecosystems.

\subsection{Forests as an Ecosystem}

Forests, like some other natural resources, perform a set of functions to meet the needs of people. They are renewable and complex ecosystems capable of providing a wide range of environmental, economic, social and cultural benefits (Cavatassi, 2004; Pak et al., 2010). Besides, they have been central to human survival and makes significant direct and indirect contributions to human welfare (Sharma 1992; Barbier et al., 1994;Dogru, 2001; Chaudhury, 2006; Wu et al., 2010). For example, forests are increasingly exposed to intensive recreational use and leisure activities (Cole, 1996) and are an important tourist destination which attracts both local and international tourists who visit throughout the year (Mugambi, 2006). In general, human beings benefit from processes or structures within forest ecosystems that give rise to a range of goods and services (Anderson et al., 2010).

According to World Bank, 2001 approximately 70 million people, many of whom are indigenous, live inside the forests. Another 735 million rural people live in or near forests and savannas, relying on them for much of their fuel, food and income - or converting them to croplands and pasture. Globally, more than 1.6 billion people, many of them poor, depend directly on forests for food or fuel. About 11 million are employed in the formal forest sector, and about 2-3 times more in the informal sector. Recent research by CIFOR highlights the significant contribution forests make to livelihoods. On average, households in forest communities derive 24 percent of their income from forests (EFTEC, 2005). Moreover much of the world's drinking water comes from catchments that are or would naturally be forested. There appears to be a clear link between forests and the quality of water coming out of a catchment, a much more sporadic link between forests and the quantity of water available (World Bank/WWF, 2003).
However, due to human population growth, migration and industrialization, and other socio-economic changes the world's forest resources severely misused (Sharma 1992; Barbier et al 1994). That is, at the present time, 14 to 16 million hectares of tropical forests are lost each year (Roper, 1999). In the case of Ethiopia, in 1970's $4.75 \%$ of the country was covered by natural high forest, however, ten to fifteen years later, only left with $0.2 \%$ undisturbed natural forest (Reusing, 2002). Undervaluation of the benefits (watershed value) of forest goods and services has been recognized as one of the main reason of deforestation (Lette et al., 2002).

Because, forest land traditionally been considered as of lower economical value than agricultural land (Font et al., 2000). Yet, in recent decades, concerns have arisen about the proper valuation of the world's forest and progress has been achieved in developing valuation methods (Kramer et al. 1997; Wu et al., 2010). That is, in order to effectively manage natural resources, decision makers may attempt to take into account the values of all aspects of the resources and understand how those values interrelate (Mitchell and Carson, 1989). This estimating money values for ecosystem services (forest) which do not normally have prices are important for making decisions (Pearce, 2002).

Given this background, the objective of this paper was to review the economic value of forest ecosystem services especially in maintaining and improving water quality and also to highlight the commonly applied techniques that are applied in the valuation of these economic values.

\section{Economic Values of Forest Ecosystem}

Economic value is anthropocentric and has value only if human beings value them. That is, forest goods and services have no value in their own right; rather, their value is defined only in the context of human welfare (CBD, 2001; Krieger, 2001). Economists use the term total economic value (TEV) to refer to the various benefits of natural resource (example forest resource) (Pearce et al., 1989) and its components can be summarized as follows (Figure 1):

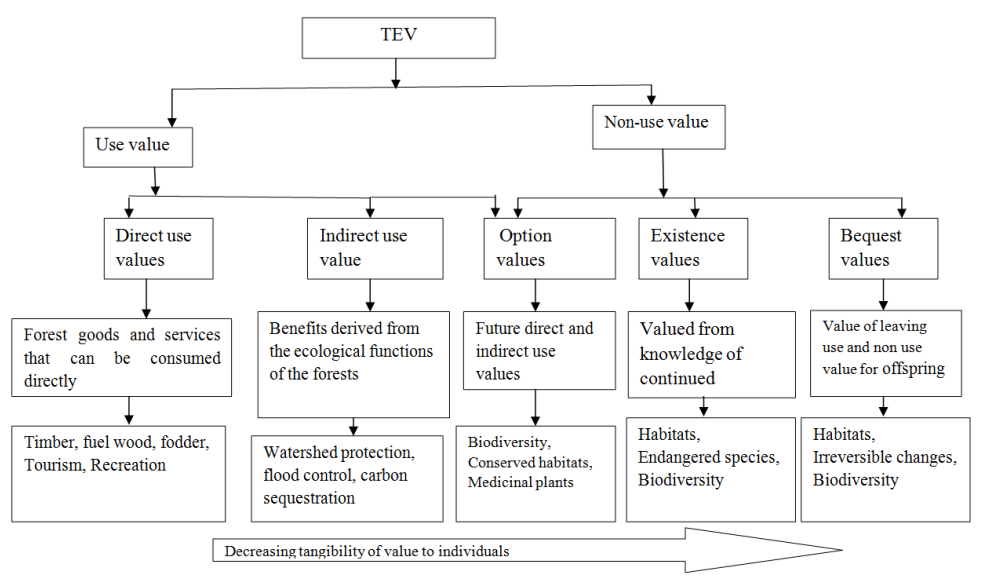

Figure1.Components of the TEV of forest ecosystem. 


\subsection{Use Values}

\subsubsection{Direct-Use Values}

Arise from direct interaction with resources (example forest) and may be consumptive uses and non-consumptive uses. It includes recreation, education and research, timber production etc (Bishop, 1999; Turner et al. 2004).

\subsubsection{Indirect-Use Values}

Indirect-use valuesare associated with services provided by resources (forest) but that do not entail direct interaction (Turner et al. 2004). That is, ecological function values are more difficult to measure the quantities and not usually traded in marketplaces. But, it is possible to find the shadow values of the resource Munasinghe and Schwab, 1993; cited in FAO, 2006).

\subsection{Non-Use Values}

These refer to the intangible benefits derived from the mere existence of forests and their components beyond their current use possibilities. That is, all other benefits which cannot be characterized in terms of a current or future physical interaction between the forest and consumers (Bishop, 1999).

\subsubsection{Bequest Value}

It is the value an individual place on his/ her satisfaction attributed to the continued existence of a resource for future possible benefit of others, either known or unknown to him or her (Perman, 2003).

\subsubsection{Existence Value}

It relates to the value of ecosystem assets irrespective of current or optional uses. Empirical measures of existence values based on donations to conservation organizations, or on the CVM suggest these can be a significant element in TEV (Agudelo, 2001).

Option value which describes the fact that some individuals who do not wish to use the resource now are willing to pay or forgo current benefits to preserve the resource for future generations or for some future use. This therefore clearly represents a non-use value for the current generation; but depending on its potential use by future generations, an option value could be either a use value or a non-use value (Agudelo, 2001; Perman, 2003).

\section{Forests Provision on Watershed Benefits}

A clean and reliable water supply is one of the most important benefits of well-managed forests and is a resource that generates immense economic value for communities and businesses throughout the world. This value is manifested in four types of watershed-related ecosystem services that forests anywhere can provide (Hanson et al. 2010):

\subsection{Water Flow Regulation}

Forestsand forested wetlands affecthe timing andmagnitude of water runoff and water flows. Someforestecosystems act as sponges, intercepting rainfall and absorbing water through root systems. Water is stored in porous forest soil and debris and then slowly released into surface water and groundwater. Through these processes, forests recharge groundwater supplies, maintain base-flow stream levels, and lower peak flows during heavy rainfall or flood events. Maintaining natural flow patterns is essential for preserving the integrity of riparian and in-stream habitats and the fish and wildlife populations that depend on them. Likewise, forests reduce storm water runoff by intercepting and storing rainfall. According to one study, less than five percent of rain falling on a forest is converted to runoff, while 95 percent of rain falling on impervious surfaces such as concrete is converted to runoff (Cappeilla, Schueler, and Wright, 2005)

\subsection{Water Purification}

According to US resource council report 2008 two thirds of the world water originates from forested lands. This water comes from precipitation that is filtered through forests, and much of it ends up in streams (Smailand Lewis, 2009). Forests help prevent impurities mostly those from nonpoint source pollution from entering streams, lakes, and ground water. Root systems of trees and other plants keep soils porous and allow waterto filter through various layers of soil before entering groundwater. Through this process, toxics, excess nutrients, sediments, and other substances can be filtered from the water. Leaves and other debrison the forest floor play a role, too, by preventing soil loss due to wind and rain, thereby preventing siltation of water ways.

\subsection{Erosion Control}

Forests help keep soil intact and prevent it from eroding into nearby bodies of water in a number of ways. By intercepting rain, a forest canopy reduces the impact of heavy rainfall on the forest floor, reducing soil disturbance. Leaves and natural debris on the forest floor can slow the rate of water runoff and trap soil washing away from nearby fields. Tree roots can hold soil in place and stabilize stream banks. In addition, coastal forests and forested wetlands protect coastlines by absorbing some of the energy and impact of storm surges, thus reducing erosion, salt water incursion, and other on shore impacts (Smailand Lewis, 2009).

\subsection{Freshwater Supply}

The numerousstreams and lakes found in forests provide fresh water for a variety of in-stream and off stream uses. In-stream uses those that occur within the water body itself include electricity generation by hydroelectric plants, as well as recreation and wildlife habitat. Off-stream uses those that 
occur outside the water body include domestic and industrial water supplies and irrigation (Smail and Lewis, 2009).

\section{Economic Value of Forests Ecosystem on Watershed}

A watershed is an area of land that drains into a common water source. Because watersheds connect and encompass terrestrial, freshwater, and coastal ecosystems, they perform a wide variety of valuable services, including the supply and purification of fresh water, the provision of habitat that safeguards fisheries and biological diversity, the sequestering of carbon that helps mitigate climatic change, and the support of recreation and tourism. In the parlance of ecological economics, watersheds are natural assets that deliver a stream of goods and services to society. Commercial markets, however, value these services only partially if at all (Postel and Thompson, 2005).

Economic valuation is a tool used to estimate the utilitarian value of ecosystem services. Typically, ecosystem services are not traded in any formal markets and therefore lack an ascribed monetary value (Band, 2010). As a result valuation of watershed services also implies understanding the different types of benefits a watershed offers to ecosystems and society. A forest watershed not only functions ( like a basin which receives and stores water from precipitation, surface runoff, or infiltration), but also cleans water, retains sediments, provides habitats for wildlife, sinks $\mathrm{CO}_{2}$, and offers many environmental amenities for humans (Brauman et al., 2007; Locatelli \& Vignola, 2009) cited in (Postel and Thompson, 2005).

Water quality and quantity conservation practiced at the watershed level creates benefits within and beyond the management area of interest. The magnitude of the benefits also depends considerably on economic policies accompanying conservation measures. One of the most important ecosystem functions is a consistent supply of water, which is needed for domestic, agricultural, industrial, and tourism needs. As important, forests slow the flow of water from steep mountainsides areas. This slow movement of water flowing through streams maximizes aquifer recharge and prevents flooding during heavy rains that cause topsoil erosion and sedimentation (Ralph, 2010).

Healthy forests and wetland systems provide a host of watershed services. Watersheds with a high proportion of land covered by intact forests and wetlands are particularly effective at moderating runoff and purifying water supplies. The vegetation and soils of forests and wetlands have a remarkable capacity to filter out contaminants and trap sediment that would otherwise enter rivers, lakes, and streams (Postel and Thompson, 2005). Their financial value becomes particularly apparent when the costs of protecting an ecosystem for improved water quality are compared with investments in new or improved infrastructure, such as purification plants and flood control structures - in many cases it is often cheaper and more efficient to invest in ecosystem management and protection (Knowler, 2008).

The ability of healthy watersheds to moderate water flows and purify drinking water supplies is one of their most capital and treatment costs than would otherwise be the case. Indeed, the raw water delivered to the utility's treatment plant is so clean that the only treatment given is chlorine for disinfection; if turbidity increases significantly during heavy rains, the water is run through sand filters first but this is rarely needed (Quintero, 2004). The water purification service can reduce drinking water treatment cost. For instance study in US shows twenty seven water supply systems from around the countryfound that from $50-55 \%$ of the variation in operating water treatment cost can be explained by the percentage of forest cover in the water source area(Ernst, 2004). The erosion control service reduces the deposition of sediment behind hydrologic dams and thereby reduces the need for expensive dredging (Hanson et al, 2011).

Watersheds without adequate protection inevitably deliver less clean, less reliable water to their downstream dependents. The conversion of natural watershed lands to agricultural, industrial, or urban uses adds to that watershed's pollution burden while simultaneously diminishing its ability to assimilate and process those pollutants. Deforestation, road construction, clear-cutting, and poor farming practices can send large influxes of eroded sediments into rivers and streams, markedly degrading the quality of water and of aquatic habitats (Calder, 2000; Newson, 1992).

Other ecosystem services provided from healthy watersheds and hydrologic functions are drought mitigation, traditional cultural resources, recreation, and preservation of unique native species. The cost of replicating any of these essential services through technology or engineering is staggering and often unnecessary if forethought and restraint is practiced under the enticement of quick economic gain (Ralph, 2010).

\section{Forest Ecosystems Role in the Maintaining Water Quality}

People have settled historically in areas rich with natural resources, and today most of the world's population lives downstream of forested watersheds (Reid, 2001). Societies have created strong cultural links with forests, and it is widely assumed that forests help to maintain a constant supply of good-quality water. Conversely, loss of forests has been blamed for problems ranging from flooding to aridity.

Forests provide shade, which moderates water temperatures, and provide a source of organic debris and nutrients, which are used by aquatic organisms. Natural processes in forested areas, such as landslides, channel erosion, blowdown, and wildfire, can affect water quality by creating temporarily increased concentrations of sediment, increased stream temperatures, and (or) increased nutrient concentrations (Harr and Fredriksen 1988). Forests also modify the chemistry of incoming precipitation as a result of vegetation and soil interactions. Nutrient movement within forest ecosystems 
involves uptake and retention by biota, which retards chemical or nutrient movements to surface waters (ibid). Thus, natural disturbances and management activities that remove or disturb forest vegetation or alter hydro chemical flow paths may change dissolved and chemical particulate concentrations and fluxes in water bodies.

In fact, the hydrological role of forests remains a subject of debate. Some of the common assumptions about the benefits that forests bring are wrong in most situations; for example, most forests do not increase water flow in a catchment (in fact the reverse is often the case), nor do they necessarily control flooding. On the other hand, some positive benefits, including particularly their potential to supply relatively pure water, are frequently overlooked. Impacts of forests are influenced by many factors including the age and species of the trees, the amount of watershed under forest, soil, and climate and forest management practices (Bruijnzeel, 1990).

A meta-study conducted for the World Wide Fund for Nature (WWF) on the role of forest protection in drinking-water provision (Dudley and Stolton, 2003), including a survey of more than hundred of the world's most populous cities, revealed - as described below - a clear link between forests and the quality of water coming out of a catchment, a much more sporadic link between forests and the quantity of water available and a variable link between forests and the constancy of flow.

Forested watersheds generally offer higher-quality water than watersheds under alternative land uses, if only because virtually all the alternatives - agriculture, industry and settlement - are likely to increase the amounts of pollutants that enter headwaters (Newson and Calder, 1989). Quality of water can also be higher because forests sometimes help to regulate soil erosion and reduce sediment load, although the extent and significance of this function may vary. Undisturbed forest with understory, leaf litter and organically enriched soil is the best cover for watershed for minimizing erosion by water. While forests are less able to control some contaminants (the human parasite Giardia lamblia, for example) in most cases the presence of forests can substantially reduce the need for treatment for drinking water and thus radically reduce costs of supplying water (FAO, 2008).

\section{Empirical Study of Forest Ecosystem Services}

Costanza et al., (1997b) (cited in identified 17 specific goods and services, but estimate the economic values of only 14, 13 and 8 specific goods and service all forest, tropical forest and in temperate boreal respectively.Generally, the study of Costanza et al., (1997b) provides a revealing but rough estimate of the magnitude of ecosystem service values on a global scale, and the value of goods and services of global forest varies for different types of forest. Table 1 shows value varies by forest type and type of ecosystem good and service.
Table 1. Monetary Estimates of Forest Ecosystem Values.

\begin{tabular}{|c|c|c|c|c|}
\hline \multirow{2}{*}{$\begin{array}{l}\text { Ecosystem good } \\
\text { or service }\end{array}$} & \multirow{2}{*}{$\begin{array}{l}\text { Market } \\
\text { Nature of } \\
\text { service }\end{array}$} & \multicolumn{3}{|c|}{$\begin{array}{l}\text { Global values by forest type } \\
\text { (\$/acre) }\end{array}$} \\
\hline & & $\begin{array}{l}\text { All } \\
\text { forests }\end{array}$ & Tropical & $\begin{array}{l}\text { Temperate/ } \\
\text { Boreal }\end{array}$ \\
\hline Climate regulation & NM & 57.1 & 90.2 & 35.6 \\
\hline $\begin{array}{l}\text { Disturbance } \\
\text { regulation }\end{array}$ & NM & 0.8 & 2 & n.a. \\
\hline Water regulation & NM & 0.8 & 2.4 & 0 \\
\hline Water supply & M,NM & 1.2 & 3.2 & n.a. \\
\hline $\begin{array}{l}\text { Erosion control and } \\
\text { sediment retention }\end{array}$ & NM & 38.8 & 99.1 & 0 \\
\hline Soil formation & NM & 4 & 4 & 4 \\
\hline Nutrient cycling & NM & 146.1 & 373.1 & n.a. \\
\hline Waste treatment & NM & 35.2 & 35.2 & 35.2 \\
\hline Biological control & NM & 0.8 & n.a. & 1.6 \\
\hline Food production & M & 17.4 & 12.9 & 20.2 \\
\hline Raw materials & M & 55.8 & 127.5 & 10.1 \\
\hline Genetic resources & M,NM & 6.5 & 16.6 & n.a. \\
\hline Recreation & M,NM & 26.7 & 45.3 & 14.6 \\
\hline Cultural & NM & 0.8 & 0.8 & 0.8 \\
\hline Total & & 392.1 & 812.2 & 122.2 \\
\hline
\end{tabular}

Note: n.a. = not available. "NM" denotes a good or service non-market in nature. "M" denotes marketed good or service. "M, NM" denotes a good or service that has significant market and non-market characteristics.

Source: Costanza et al., (1997b)

In table 2 below, the value of Ethiopia's forest ecosystems services of nutrient cycling and cultural isscoring the highest and lowest value respectively.

Table2. Annual economic value of forest ecosystem services in Ethiopia.

\begin{tabular}{ll}
\hline Forest service type & Value of Ethiopia's forest ecosystems (USD) ${ }^{* *}$ \\
\hline Climate regulation & 891536800 \\
Water regulation & 23721600 \\
Water supply & 31628800 \\
Erosion control and & 979504400 \\
sediment retention & 39536000 \\
Soil formation & 3687720400 \\
Nutrient cycling & 164074400 \\
Genetic resources & 447745200 \\
Recreation & 7907200 \\
Cultural & $6,273,374,800$ \\
\hline
\end{tabular}

*Please note that this estimate is based on the ca. 4,000,000 ha of high forest in Ethiopia WBISPP, 2001 (cited in Tsegaye, 2008) and does not include the vast areas of woodlands $* *$ Calculated from the $\$ /$ hectare estimates of

Costanza et al. (1997b) based on a conversion factor of 2.471 acres/hectare.

\section{The Need for Forest Ecosystem Valuation}

Economic valuations of natural resources (example, hydrological value of forest resource) would help in determining the tradeoff between economic development and quality of environment (Verma, 2009). It provides ways to measure the benefits and costs of different policy options and 
used to investigate how individuals make trade-offs between ecosystem service and other commodities. Generally, economic valuation helps policy makers to set standards and objectives related to ecosystem service, develop approaches to evaluate competing policy issues, design incentives that encourage ecosystem service protection, and evaluate policy outcomes (Anderson et al., 2010).

What is more, economic valuation helps to incorporate public willingness to pay in forest and environmental conservation project, evaluate competing forestry and environmental projects, and allocation of public spending on forest and environmental conservation. Besides, it optimizes forest investment and forest goods and ecological service values of forest ecosystem. Predominantly, economic valuation helps to adjust forest resource to national accounting (Ghani, 2006).

\section{The Impact of Forest Practices on Water Quality}

Forest practices can have positive or negative impacts on water quality. Forested areas serve as filters, which generate clean, clear water. Each of us has to ensure that our activities within forests do not interrupt this supply of clean water. With proper planning and careful management of activities, we can minimize the negative water quality impacts of forest management activities (Flynn, 1999).

The most obvious impact associated with forestry activities is erosion of sediment into water bodies, and it is this problem most people think about when they think about forestry and water pollution. The easily observed problem of sediment in a water body is usually the most serious impact to water quality associated with forest management activities. However, a number of other pollutants, associated with forestry activities, can impact water quality. These include fertilizers and herbicides if improperly applied and elevated water temperature if streamside management zones are not maintained. In addition, there can be an increase in biological oxygen demand (the amount of oxygen necessary to allow breakdown of organic matter by microorganisms) if large amounts of organic material (tops and branches) are deposited into stream channels (Flynn, 1999).

\subsection{Erosion of Sediment}

Besides the obvious aesthetic impacts, there are a number of reasons why excess sediment in a water body is considered pollution. Sediment in a stream or lake can settle out of suspension and fill up the small spaces in streambeds or lake bottoms (Flynn, 1999). These small spaces are usually occupied by bottom dwelling organisms as well as the young of many aquatic organisms. Sediment deposited on these organisms will kill them by smothering them. Loss of these organisms can have a significant impact on the diversity and health of a water body.If sediment deposition is heavy enough, it can decrease the water-holding capacity of a stream, lake, or reservoir by physically filling it up. This can result in increased flooding and/or decreased water supply if the water body serves as a reservoir for drinking water (ibid).

Sediments that remain suspended in the water will decrease the amount of light that can penetrate through the water. Since all plants, even aquatic ones, require light for photosynthesis (the process by which plants use sunlight to produce their own food), excess amounts of suspended sediment in the water will weaken or kill plants. Aquatic organisms that depend on sight to locate food will also be negatively impacted by the decrease in light penetration. Sediment suspended in the water can also damage the gills of fish, making it more difficult for them to get enough oxygen (Flynn, 1999).

\subsection{Logging Debris}

Another readily apparent water quality problem is the deposition of logging debris in water ways. Virtually all streams have some amount of organic debris present. This organic material provides food and cover for various aquatic organisms. However, excessive amounts of organic debris can adversely affect water quality in several ways (Flynn, 1999).

First, the physical presence of greater than normal amounts of debris interferes with the natural hydrology of a waterway. Water may back up and flood areas that are not normally wet, movement of aquatic organisms may be hindered, and parts of small streams may actually be starved of water due to the damming effect of upstream debris (Flynn, 1999).

In addition, as this debris begins to decay, there is an increased demand for oxygen by microorganisms breaking down the organic matter. This increased oxygen demand can deplete the oxygen dissolved in the water and kill aquatic organisms (Flynn, 1999).

\subsection{Forest Chemicals}

Forest chemicals include herbicides, insecticides, fungicides, and fertilizers. Typically, private landowners will use these chemicals for forest management infrequently and will apply them at low rates. As long as the label instructions are followed, there is little danger that forestry activities will contribute in any significant way to impaired water quality from these chemicals (Flynn, 1999).

\subsection{Streamside Management Zones}

Another problem that can affect water quality results from a lack of adequate stream side management zones. These vegetated zones are located adjacent to water bodies and serve several purposes (Flynn, 1999).

The primary purpose of a streamside management zone is to filter water before it enters the stream. This vegetated zone, if properly established, will serve to trap any sediment that erodes from disturbed soil areas. In order for streamside management zones to be effective sediment filters, the slope adjacent to the stream must be taken into account when deciding the width of the zone (Flynn, 1999)

A secondary purpose is to provide continued shading of the water way. This shade will help pre- vent development of elevated stream temperatures. Elevated stream temperature 
reduces the amount of oxygen that can be dissolved in the water. This type of water pollution has major impacts on both animal and plant life in water bodies. Typically, stream water temperature is more sensitive in smaller streams. A third benefit of streamside management zones is the provision of cover for wildlife. The state best management practice (BMP) manual offers advice for establishment of these streamside management zones (Flynn, 1999).

\subsection{Harvesting Effects}

Forest harvesting can influence water quality, particularly the concentrations of suspended solids (sediment) in stream water. Besides when timber is harvested, direct sunlight reaches the forest floor and increases evaporation from soil and litter. However, transpiration is reduced in proportion to the reduction in leaf surface area. The net effect is a reduction in evapotranspiration. More water is stored in the soil and more supplies groundwater and streams (Flynn, 1999).

Forest harvesting can affect microbiologically mediated soil processes. For example, the creation of forest openings by harvesting or canopy gaps by blow down, or the falling of old-growth trees, can increase nitrification in the soil (Feller 2005). This may increase nitrate flow through the soil, which may reach surface water bodies. This flow enhanced if nitrogen fixation also increases after forest harvesting. Nitrogen fixation increases existing nitrogen pools and may increase nitrate mobility. Conversely, nitrate flow can decrease in forests because of denitrification, especially in riparian forests where anaerobic conditions may result from increased soil moisture and increased dissolved organic carbon (DOC) in soil solution (caused by enhanced decomposition of organic material) (Feller 2005,). Recognition of this process is commonly used in designing riparian or streamside management zones to improve water quality from upslope sources (Stednick 2010).

Timber harvesting operations typically involve the use of heavy machinery and thus have the potential disturb the forest floor. This disturbance may expose mineral soil, reduce the soil's absorbency, lead to erosion, and divert and concentrate overland flow. Sediment and nutrient-laden overland flow as a result of erosion from harvesting operations can lessen water quality that directly affects living organism and drinking water supplies if it gets into nearby streams, rivers, wetlands, lakes and ponds. Timber harvesting may also diminish the level and therefore the benefits of vegetation next to water bodies (USDA, 2008).

\section{Economic Valuation Techniques}

Economists have devoted considerable effort in recent years to developing and applying methods for valuing non-market benefits of environmental resource (like forest) in monetary terms (Freeman 1993). All of the methods attempt to express consumer demand, i.e. the willingness-to-pay (WTP) of consumers for a particular non-marketed benefit in monetary terms. In short, these valuation methods attempt to express the utility derived from non-market goods and services (Bishop, 1999).These valuation methods can generally be classified into two groups, namely, direct and indirect methods.

\subsection{Indirect Valuation Methods (IVM)}

IVM looks for substitute markets in which the environmental good is implicitly traded (Lancaster, 1966). A key element in the theoretical framework used to model this behavior and to relate it to the desired monetary measures of value and welfare change is the model of the optimizing behavior of an economic agent that relates the agent's choices to the relevant prices and constraints (Freeman, 1993; Tietenberg, 2003). It includes hedonic pricing method, travel cost method etc. But, IVM is not the only method which used to estimate the value of intangible goods.

\subsection{Direct Valuation Methods (DVM)}

DVM seek to elicit preferences directly through the questioning of individuals on their willingness to pay/willingness to accept for a good or a service. DVM includes the contingent valuation method, contingent ranking etc (Turner et al. 2004).

\subsection{Contingent Valuation Method (CVM)}

Since the early 1970 s the contingent valuation technique has been used by economists to measure the benefits of a wide variety of goods (Mitchell and Carson, 1989). It has been widely applicable methods in valuing direct and indirect values of environmental goods and services (Whittington et al. 1990; Whittington 1998). CVM used to measure the compensating or equivalent variation for the good in question. Compensating variation is interpreted as the maximum amount that the individual would be willing to pay for the opportunity to consume at the new price set. Accordingly, WTP is defined as the amount that must be the users pay from his income to maintain utility constant (Freeman, 1993).

In early application of the CVM, respondents are often asked open-ended questions about their WTP. It is nowadays less and less frequently used due to obvious respondent difficulty in answering the payment question, which results in many missing values for WTP (Albertini and Cooper, 2000). The most widely used approach to eliciting information about the respondent's WTP dichotomous choice format. The dichotomous choice approach take off a behavior in regular market where people usually purchase or decline to purchase a good at a stated price (Hanemann et al., 1991).

According to, Albertini and Cooper (2000), the compensating variation when a person purchases an improvement in environmental quality can be specified as:

$$
\mathrm{U}\left(\mathrm{M}-\mathrm{WTP}, \mathrm{Pi}, \mathrm{Q}_{1} ; \mathrm{Xi}\right)=\mathrm{U}\left(\mathrm{M}, \mathrm{Pi}, \mathrm{Q}_{0} ; \mathrm{Xi}\right) \text {; }
$$

Where:U- denote the indirect utility function,

M- Income

Pi- Vector of prices faced by the individual

$\mathrm{Q}_{0}, \mathrm{Q}_{1}$-alternative levels of the good or quality indexes $\left(\mathrm{Q}_{1}\right.$ refers to improvedenvironmental quality and $\mathrm{Q}_{0}$ unimproved one).

WTP- willingness to pay 
$\mathrm{Xi}$ - respondents characteristics (such as age, education, wealth, etc.)

Due to the hypothetical nature of the CVM, the method of payment used and other factors, the estimated WTP can be biased. The first possible bias is strategic bias and occurs when respondent understate and overstate the true values of the WTP (Mitchell and Carson, 1989).

Other problems are design biases and these problems are related to the design of the survey and they include starting point bias. Moreover, a problem arises from the hypothetical nature of the CVM questionnaire is that incorrect WTP assessments by the respondent are not punished. In general, the extent to which hypothetical market bias occurs seems to depend on how the questions are asked in the CVM questionnaire and on how realistic respondents feel the hypothetical market is (Hanley and Spash, 1993). These biases should and can be avoided as much as possible by performing statistical tests during survey design (e.g. after pretesting) (Mitchell and Carson, 1989).

\section{Conclusion}

The importance of natural forest ecosystems to human well-being cannot be overstated. What this review makes clear that forest ecosystem service provides important portion of the total contribution to economic development and social welfare in the maintaining and improving water quality. Water in adequate quantity and quality to meet human needs is essential, and forests have direct and indirect roles in providing such water. However, in order for conservation of forest areas to be economically feasible, such forest areas need to secure a financial return in excess of alternative uses. It is increasingly recognized that both the availability and the quality of water are strongly influenced by forests and that water resources in many regions are under growing threat from overuse, misuse and pollution. The relationship between forests and water is therefore a critical issue that must be accorded high priority. A key challenge for land, forest and water managers is maximizing the wide range of forest benefits without detriment to water resources and ecosystem function. To address this challenge, there is urgent need for better understanding of the interactions between forests/trees and water (particularly in watersheds), for awareness raising and capacity building in forest hydrology, and for embedding this knowledge and research findings in policies. There is also need to develop institutional mechanisms to enhance synergies in forests and water issues, and to implement and enforce national and regional action programmes.

In the past, forest and water policies were often based on the assumption that under any hydrological and ecological circumstance, forest is the best land cover to maximize water yield, regulate seasonal flows and ensure high water quality. Following this assumption, conserving (or extending) forest cover in upstream watersheds was deemed the most effective measure to enhance water availability for agriculture, industrial and domestic uses, as well as for preventing floods in downstream areas. Best Forest Management Practices are techniques minimize negative effects on water quality.Therefore, understanding the role of forests as providers of water related services and the way economic valuation should measure these services still needs clarification and further development.

\section{References}

[1] Agudelo, J.I., (2001). The Economic Valuation of Water Principles and Methods. Value ofWater Research Report Series No. 5.

[2] Alberini, A. and Cooper, J., (2000). Application of Contingent Valuation Method in DevelopingCountries. Economic and Social Development Paper. FAO, No. 146, Rome.

[3] Anderson, J., Gomez W., C., McCarney, G., Adamowicz, W., Chalifour, N., Weber, M.,Elgie,S., and Howlett, M. (2010). Ecosystem service valuation, market-base instruments andsustainable forest management: a primer. State of Knowledge primer. Sustainable ForestManagement Network, Edmonton, Alberta. 25 pp.

[4] Band,L., (2010). Forest Ecosystem Processes at the Watershed Scale: Ecosystem services

[5] Barbier, E.B., Burgess, J.C., Bishop, J. and Aylward, B. (1994). The Economics of theTropicalTimber Trade. Earthscan. London.

[6] Bishop J.T. (ed.) (1999).Valuing Forests: A Review of Methods and Applications inDevelopingCountries. International Institute for Environment and Development (IIED), 3Endsleigh Street, London WC1H ODD, UK

[7] Bruijnzeel,1.A. (1990).Hydrology of moist tropical forests and effects of conversion: a state ofknowledgereview. Paris, France, United Nations Educational, Scientific and CulturalOrganization(UNESCO) International Hydrological Humid Tropics Programme.

[8] Cappeilla, K., T. Schueler, and T. Wright. (2005). Effect of land cover on runoff and nutrientloads in a watershed. Urban Watershed Forestry Manual, Part 1: Methods for IncreasingForest Cover in a Watershed. NA-TP-04-05. 94. Ellicott City, MD: USDA Forest Service

[9] Cavatassi R., (2004).Valuation Methods for Environmental Benefits in Forestry and WatershedInvestment Projects. ESA Working Paper No. 04-01.

[10] Chaudhury, P., (2006).Valuing recreational benefits of urban forestry - a case study ofChandigarh city, Ph D thesis, Forest Research Institute (Deemed University), Dehradun,

[11] Cole, D. (1996). Wilderness recreation use trends, 1965 through 1994. USDA Forest Service,Rocky Mountain Research Station-Ogden. Research paper INT -RP- 488.

[12] Costanza, R, d'Arge, R, de Groot, R, Farber, S, Grasso, M, Hannon, B, Limburg, K,Naeem, S,O'Neill, R V, Paruelo, J, Raskin, R G, Sutton, P and M van den Belt. (1997b). The Valueof the World's Ecosystem Services and Natural Capital. Nature 387: 253-60.

[13] Daily, G.C. (Ed), (1997). Nature's Services: Societal Dependence on Natural Ecosystems. IslandPress, Washington, D.C 
[14] De Groot, R.S., M.A. Wilson, R.M.J. Boumans, (2002). A typology for the classificationdescription and valuation of ecosystem functions, goods and Services. EcologicalEconomics 41: 395 - 408 .

[15] Dogru M., (2001). Planning and Management of Forest Resources in Turkey (Draft), Assistancefor the Preparation of a National Programme for Turkey. Earthscan. London.

[16] Dudley, N. and Stolton, S. (2003). Running Pure: The importance of forest protected areas todrinking water. A research report for the World Bank / WWF Alliance for ForestConservation and Sustainable Use, United Kingdom.

[17] Economics for the Environment Consultancy (EFTEC), (2005) The Economic, Social andEcological Value ofEcosystem Services: A Literature Review, 16 Percy St, London W1T1DT.

[18] Ernst, C. (2004). protecting the source: Land conservation and the future of America's drinkingwater. Water protection series. San Francisco,CA: the trust of Public Landand Americanwater worker Association online at:http://www.tpl.org/content_documents/protecting thesource_04.

[19] FAO, (2008). Forests and water; A thematic study prepared in the framework of the global forest assessment. feedback and evolution in developing mountainous catchments. EGU General Assembly Vol. 12, EGU2010-7150, United states

[20] Feller, M.C. (2005). Effects of clearcutting and slash burning on stream temperature insouthwesternBritish Columbia. Water Resour. Bull. 17(5):863-867.

[21] Flynn, K. (1999) Forest Practices And Water Quality: Guidelines For Landowners Alabama A \&M and Auburn University.

[22] Font X., and John Tribe (eds), (2000). Forest tourism and recreation. Case studies inenvironmental management. Faculty of leisure and tourism, Buckinghamshire chilterns University College, High Wycombe, UK.

[23] Food and Agricultural Organization (FAO), (2006).Valuation ofPollinationServices:Review ofMethods Pollination, University Of Bonnmethods.

[24] Freeman III.A.M., (1993). The Measurement of Environmental and Resources Values: Theoryand Methods, Resources for the Future, Washington, D.C.

[25] Ghani A.N.A. (2006). Economic valuation of forest ecosystem service in Malaysia University Putra, Malaysia (availableatwww.jst.go.jp/.../09_seminar_ASTS_penang_10_1 4_march_2006_Awang_Noor.p̄jf)

[26] Hanemann, M., Loomis, J. and Kaninen, B. (1991). Statistical Efficiency of DoubleBoundedDichotomous Choice Contingent Valuation. American Journal of AgriculturalEconomics, 73(4), 1255-63.

[27] Hanson, C., L. Yonavjak, C. Clark, S. Minnemeyer, A. Leach, and L. Boisrobert. (2011).Southern forests for the future. Washington, DC: World Resources Institute.

[28] Harr, R.D. and R.L. Fredriksen. (1988). Water quality after logging small watersheds within theRun watershed, Oregon. Water Resour. Bull. 24(5):1103-1111.

[29] Hawkins, K., (2003).Economic Valuation of Ecosystem Services. University of Minnesota.
[30] Knowler,.D., (2008).Master's thesis project title: Valuing the Water Supply Service ofTemperate Coastal Rainforests inSouthwestern British Columbia

[31] Kramer, R., R. Healy, and R. Mendelsohn. (1997). Forest Valuation. Chapter 10. In ManagingtheWorld's Forests, Narendra Sharma (ed.). World Bank Natural ResourcesDevelopmentSeries, Arlington, VA.

[32] Krieger, D.J., (2001).The economic values of forest ecosystem services: a review. Thewilderness society, $1615 \mathrm{M}$ Street, NW, Washington, D.C. 20036.

[33] Lancaster K., (1966). A new Approach to Consumer Theory. J Polit Econ; 84:132-57.

[34] Lette, H., Boo, de H. (2002). Economic Valuation of forests and Nature, A support tool foreffective decision-making. Theme studies series 6, IAC Wageningen, theNetherlands.

[35] Mitchell, R.C., Carson, R.T. (1989). Using Surveys to Value Public Goods: The ContingentValuation Method. Resources for the Future, Washington, $463 \mathrm{p}$

[36] Mugambi D., D., Mugendi, A., Wambugu and J., Mburu (2006) Estimating RecreationalBenefits of Kakamega Forest in Kenya Using the Travel Cost Method

[37] Newson MD, Calder IR (1989). Forests and water resources: problems of prediction on a regional scale.

[38] Pak M., M.F., Türker and A., Öztürk (2010). Total economic value of forest resources in Turkey.African Journal of Agricultural Research Vol. 5(15), pp. 1908-1916, 4August, 2010.

[39] Pearce, D., (2002). Economic Valuation with Stated Preference Techniques: Queen's Printer andController of Her Majesty's Stationery Office.

[40] Pearce, D.W., Markandya, A. and Barbier, E.B. (1989). Blueprint for a Green Economy.

[41] Perman, R., ( 2003). Natural Resource and Environment Economics. ${ }^{\text {rd }}$ edition, PearsonEducation Limited.

[42] Postel. S., L, and Thompson. B., Jr, (2005). Watershed protection: Capturing the benefits ofnature's water supply services. Natural Resources Forum 29 (2005) 98-108 Published byUnited Nations.

[43] Quintero, J.D., (2004). Lead environmental specialist for Latin America and the CaribbeanRegion, Environmentally and Socially Sustainable Development Department, The WorldBank. Personal communicationto S. Postel, Washington, D.C., 27 May.

[44] Ralph S. Hosmer, (2010). Water Quality \& Quantity: In Hawaii, the most valuable product of theforest is water, rather than wood."

[45] Reid, W.V. (2001). Capturing the value of ecosystem services to protect biodiversity. In G.Chichilenisky, G.C. Daily, P. Ehrlich, G. Heal \& J.S. Miller,eds. Managing human-dominated ecosystems, pp. 197-225. Monographs in Systematic Botany Vol. 84. StLouis, USA, Missouri Botanical Garden Press.

[46] Reusing, M. (2002). Extent and dynamics of deforestation in Ethiopia. A paper presented at theNational Conference on Forest Resources of Ethiopia: Status, Challenges andOpportunities held at Addis Ababa, 27-29 November 2002. 
[47] Roper, J., (1999). Deforestration: Tropical forest in decline. Forestry issues. Online available at:http://www.rcfa-cfan.org/english/issues.12.html (reviewed April 2006).

[48] Seager, R., A. Tzanova, and J. Nakamura. (2009). Drought in the south-eastern United States:Causes, variability over the last millennium, and the potential for future hydro climatechange. Journal of Climate 24(19): 5021-5045.

[49] Sharma, N.P. (ed.) (1992). Managing the World's Forests: Looking for Balance betweenConservation and Development. Kendall/Hunt Publishing Company.

[50] Smail, R.A., and D.J. Lewis. (2009). Forest land conversion, ecosystem services, and economicissues for policy: A review. PNWGTR-797. Portland, OR: U.S. Department ofAgriculture, Forest Service, Pacific Northwest Research Station.

[51] Stednick, J.D. (2010). Wild land water quality sampling and analysis. Academic Press, SanDiego, Calif.

[52] Tietenberg T., (2003). Environmental and Natural Resource Economics. $6^{\text {th }}$ edition, PearsonEducation, Inc, U.S.A.

[53] Tsegaye Tadesse (2008). The Values of Some Forest Ecosystem Services in Ethiopia: Discussionpaper presented at the workshop on Ethiopian Forestry at Crossroads: Proposal on NewDirection for Sustainable Development.

[54] Turner, K., S. Georgiou, R. Clark, R. Brouwer, and J. Burke,
(2004). EconomicValuation ofWater Resources in Agriculture: From the sectoral to a functional Perspective of natural resource Management, FAO, Rome, Italy.

[55] USDA (2008). Forest Service Northeastern Area Best Management

Practiceshttp://www.na.fs.fed.us/watershed/bmp.shtm.

[56] Verma M., (2009).Valuation of Forest Ecosystem Services in Uttarakhand Himalayas for setting Mechanisms for Compensation and Rewards for Ecosystem Services for communities conserving Forests of Uttarakhand State1. Buenos Aires, Argentina,

[57] Whittington D., (1998). Administering Contingent Valuation Surveys in Developing Countries.World Development. Vol.26, No.1, 21-30.

[58] Whittington, D., J. Briscoe, X. Mu and W. Barron. (1990).Estimating the Willingness to Pay forwater Services in Developing Countries: A Case Study of the Use of ContingentValuation Surveys in Southern Haiti. Economic Development and CulturalChange, 38(2): 293-311

[59] Wikipedia, (2010). World free encyclopedia. Accessed date 10 Sep., 2010

[60] Wu S., Y. Hou and G. Yuan (2010). Valuation of forest ecosystem goods and services and forestnatural capital of the Beijing municipality, China. Unasylva 234/235, Vol.61. 